\title{
Examination on the use of emoticon technique as a communication tool for narrative skills
} \\ ${ }^{a}$ Muş Alparslan University, Muş and 49100, Turkey
}

APA Citation:

Sönmez, H. (2019). An Examination on the use of emoticon technique as a communication tool for narrative skills. Journal of Language and Linguistic Studies, 15(2), 470-483.

Submission Date: 27/09/2018

Acceptance Date:25/04/2019

\begin{abstract}
The aim of this study is to examine how critically and creatively the students express their feelings and thoughts by using emoticons. In the first part, how the students expressed what they read by using emoticons was examined. In order to assess their skills for reading comprehension and the skills for expressing what they understood through emoticons, an achievement test was applied. The second part was reserved for the case study. The case analysis processes (items) were designed based on the case. In the end of the pilot application, both the achievement test and the case analysis processes (items) of the case were reviewed and completed. In actual application the findings suggested that the students were able to comprehend what they read and express their emotions and ideas in a certain context in a critical and creative way by using emoticons. Based on this finding, it has been suggested that emoticons used in many parts of the world should take place consciously in education.
\end{abstract}

(C) 2019 JLLS and Hülya Sönmez - Published by JLLS.

Keywords: Communication tool; students; emoticons; technique

\section{Introduction}

\subsection{Literature review}

People make use of emoticons in many areas of communication, primarily in computer-mediated communication (CMC) in the technology era we are living in. The most prominent aspect of this communication tool is that they can become widespread very fast. Becoming widespread fast, emoticons are used simultaneously and in a short time by people living in different parts of the world. That gives rise to a universal language which is not national or regional. Emoticons are the alphabet of this figurative language. The basic feature that distinguishes emoticons from the letters of a language is that they are the non-phoneme-based products of certain feelings and ideas. Letters constitute the phonemes of various languages while emoticons constitute the phones of the universal figurative language by means of which people express their feelings and ideas. Another feature that distinguishes them from letters is that they are more comprehensive. While the letters of an alphabet are constituted of only by a phoneme, emoticons stand for at least a single word or sentence.

\footnotetext{
${ }^{*}$ Corresponding author. Tel.: +905066118629

E-mail address: hulya.sonmez@alparslan.edu.tr or hulyasonmez49@gmail.com
} 
Emoticons emerged from various factors through time. Huang, Yen and Zhang $(2008,470)$ suggest that the effect of the emoticons on students vary based on various factors such as instant messaging and perceived usefulness. The findings of the examination suggest that emoticons are effective in creating positive emotions on the emoticon users in cases such as entertainment, personal interaction, richness in information environment and perceived usefulness. It has been found that emoticons make valuable contributions to communication methods in addition to being used for entertainment purposes (Huang et al., 2008, 470).

In addition to being a figurative communication tool, emoticons are also used for different purposes. For instance, emoticons are used as a part of the treatment for sick kids as they have a powerful effect on children. Oto, Pelit and Aydin $(2002,30)$ used smiley faces as a treatment tool in the treatment of children with strabismic and/or anisometropic amblyopia disorder. Researchers observed that those children responded treatment over time by drawing a lot of happy faces. Emoticons are also effective in children's attitudes and behaviors developed thereof. These icons are considered to be entertaining communication tools for the comprehension and expression skills. However, these icons, considered to be entertaining tools in communicative understanding and expressing skills, might play a major role in creating behavioral change over time. Siegel, Anneken, Duffy, Simmons, Hudgens, Lockhart and Shelly (2015), made use of the effective and wide range of the emoticons and studied how they created a difference in behavior on children. They used emoticons during the study in order to observe the behavioral change. They stuck smiley faces on healthy products in order to promote healthy nutrition habits in children. Hence, they aimed to draw children's attention to those target products and promote their consumption among children. The findings of the study suggested that children were more inclined to consume the products carrying smiley faces than they were inclined to consume the products without smiley faces in the school canteen (Siegel et al, 2015). In the end, they noted that emoticons were quite effective in children's developing positive attitudes and behaviors.

Emoticons are effective on both attitudes and behaviors and the change they create in human brain was observed in clinical tests. Churches, Nicholls, Thiessen, Kohler and Keage (2014), identified that there occurred some changes in people's brains when exposed to happy faces. Researchers identified that in the configural processing where the messages about emoticons were transmitted brain perceived those emoticons as faces, and when the configuration processing was dissociated, brain didn't recognize the emoticons as faces (Churches et al. 2014, 202-203).

Emoticons are divided into groups according to the functions they undertake when transferring the messages. Skovholt and Kankaanranta (2014), examined the functions of emoticons in three groups: "First, when following signatures, emoticons function as markers of a positive attitude. Second, when following utterances that are intended to be interpreted as humorous, they are joke/irony markers. Third, they are hedges: when following expressive speech acts (such as extending thanks, greetings, etc.) they function as strengtheners and when following directives (such as requests, corrections, etc.) they function as softeners (Skovholt and Kankaanranta, 2014)". Locke and Daly (2007), on the other hand, group emoticons according to the positions where they are used. If an emoticon in a communication text is at the beginning of the sentence or expression, then it is an "opener"; if it is at the end of the text, then it is a "closer"; if the emoticon is in the middle of or body of the text, then it is an "interjector". Due to their positions in a text, "openers" are the forewords of the communication text; "closers" are the signature that closes the message of the participant and "interjectors" are the comments that are hidden in the body of the message (Locke and Daly, 2007, 127-8). The frequency of use for these functions is as follows: "Closers" (74\%), openers (14\%) and interjectors (12\%). Some researchers, on the other hand, based on the effect of the emoticons they create on the individual, divide the functions of emoticons into two groups which are like and dislike (Weiquan, Zhao and Lingyun, 2014, 475). In the research conducted in laboratory environment, it was observed that emoticons begot two different effects which 
are like and dislike or positive and negative. If the individual faces a negative situation in the CMC environment, s/he expresses the case by using dislike emoticons. On the other hand, if the individual faces a positive situation, s/he expresses the case by using like emoticons. As is seen, emoticons have different functions according to the positions they are used, their effects on the individual and their purpose of use (Weiquan, Zhao and Lingyun, 2014, 475).

In parallel with the increase of their functions, the number of emoticons has increased over time. As Ekman puts it, emoticons made their debut to our lives with a single smiley. However, today they consist of many icons (cited by Ganster, Eimler and Kra“Mer, 2012). Locke and Daly $(2007,127)$ made the case clear to some extent by examining how many emoticons people express themselves with. The participants of the study used twenty emoticons to express themselves. It was noted that "smile", "grin" and "pbt" are the emoticons used most by the participants. These emoticons are different from one another and each has a universal identification. The following universal emoticons are used to indicate: :- ) smile, :- ))))) laugh, :- > wry smile, :-\} teasing smile, :-) -: both sad and smiling,:-d grinning, :-( or :( sad, :' or ; ( crying, :'-( sadly crying, :'-) fake cry, :-(( very sad etc. (Gürçayır, 2009, 115). While these emoticons are universal, some emoticons are used only in certain countries because some emoticons to express feelings were drawn differently in America and Japan: For example, the following emoticons were drawn in America: :-) smile, :-( sad, :' cry and :-)) so happy, whereas the following emoticons were drawn in Japan: $\left({ }^{\wedge}{ }_{-}^{\wedge}\right),\left({ }^{\wedge} \mathrm{O}^{\wedge}\right)$; $)$ sorry, :' cry (;_; don't cry, :-)) so happy, $\left({ }^{\wedge} \mathrm{o}^{\wedge}\right)$ happy. Halvorsen (2000), observed that emoticons show difference when used by children. In his study on bilingual children, Halvorsen (2000), studied whether the ten emoticons used frequently in both languages (mother tongue and second language) have the same meaning or not. Most of the participants suggested that the emoticons used in both languages stood for the same feeling, whereas some of the participants stated that they had more emoticons in their native languages compared to English. Another group stated that the emoticons they used in their native language were different from the emoticons they used in English (Halvorsen, 2000, 701).

These findings lead to the following questions: Do people express a certain feeling or idea by only a single emoticon? For instance, do we express our anger only by a single face? Visser, Alant and Harty $(2008,306)$, sought answers to these questions in their study. The results of the study showed that there is more than one emoticon to express an emotion. Among these, especially emotions such as happiness, sadness, fear and anger were expressed by more than one emoticon. In addition to this, it was identified that children created four different emoticons to express happiness, sadness, fear and anger and they did it by creating four different emoticons for each feeling. The fact that the emoticons used by children most were those standing for positive feelings is also curious (Visser et al., 2008, 306). Ganster, Eimler and $\operatorname{Kra}$ Mer $(2012,229)$, examined the reasons why the emoticons expressing positive feelings are used more frequently. The results of the study revealed that smiling faces (smiley faces) have a strong effect on people's mood and it was emphasized that smiley has a stronger effect than other emoticons do since a smiley changes the perception of the individual on a certain issue. So "smiley" is the most common icon in this field due to this property of its. They examined how frequently a group of preschool children used the emoticons of happy, sad, scared and angry faces. It was found that the children used the happy, angry, scared and sad faces respectively in order to express their feelings and ideas. While most of the children took part in the study drew the happy (99\%) and angry (85\%) faces more easily, some of the children had much more difficulty in drawing the scared (74\%) and sad (73\%) faces (Visser et al., 2008, 307-308).

The role of gender in the choice of the emoticon type and the frequency of use of the same is another aspect that should be explored deeply. In other words, how and to what extent the emoticons are used by girls and boys. According to Wolf (2000), girls and boys are driven by different motives to use the emoticons. The study revealed that while the girls use the emoticons for humor purposes mostly in 
environments where both girls and boys exist, boys use them for teasing or sarcasm purposes (Wolf, 2000, 882). In addition, it was found that while positive concepts such as solidarity, support, assertion of positive feelings and expressing gratitude stand out in the emoticons used by the girls, boys do not resort to such feelings often. Hudson, Sylis, Howser, Lipsett, Robinson, Pope, Hobby and Friedman (2015), emphasize that gender could be a decisive factor in using emoticons. They examined how the emoticons used in Facebook environment affected the envy feelings of girls and boys. The results are highly different in both quantity and quality as it has been found that the envy rates and reactions of male and female students to e-mails in which emoticons are used are not the same.

Starting with a smiling face to express our happiness, the emoticon trend has gradually evolved into a widespread figurative emotion alphabet with the drawing of sad, angry, scared, surprised, etc. faces. This entertaining figurative alphabet addresses people of all ages and is used widespread universally by saving people of the effort necessary to learn a language. Therefore, emoticons have had an important place in our lives as a means of communication in many fields since they have become one of the communication medium out of necessity in this era of technology. The aim of this study is to determine the impact of emoticons on students' critical and creative thinking skills. The aim of this study is to measure the effect of emoticons on the students' abilities to comprehend and express in everyday life. Answers to the following questions are sought through the problem cases in the research.

\subsection{Research questions}

- How is the role of emoticon on students to convey their critical and creative feelings and thoughts in reading, understanding and interpreting skills (reading skill)?

- How is the role of emoticon on the students' skills to convey their feelings and thoughts critically and creatively?

\section{Method}

The present study aims to identify how students express their critical and creative feelings and thoughts by using emoticons. Therefore, this is a case study of qualitative research designs. Because of focused on a case in this study, this is an instrumental case study of the types of case study (Creswell, Trans. Edt. Bütün and Demir, 2013, 99). We have been able to gather detailed and thorough data through case analysis processes (items) prepared in accordance with reading comprehension achievement test and case study during the study. We described the emoticon utilization states of elementary school students with the help of these data.

\subsection{Sample / Participants}

245 students (131 girls and 114 boys) participated in the study. These were 7th and 8th grade students who attend a public school in Istanbul. The demographic characteristics (culture, education, economy etc.) of this school were medium-level and the age of the students varied between 12 and 13 years. The students had taken the attitude scale for using emoticons in a previous study. Emoticons were quite helpful to the students in this study (Sönmez, 2018). The reason to carry out the study with the same students was to find out how the students who had found using emoticons useful (positive attitude) would express themselves by using the emoticons. 


\subsection{Instrument( $s)$}

The text for reading comprehension was chosen with the help of Turkish Language Education field specialists and the name of the text is "The Story of the Camel and the Mouse", a story from Mevlânâ's Mesnevî. Why this story was found eligible to be used in the achievement test is explained as follows: It was a short story, the language and style of the text was appropriate for the audience, the text contained different types of feelings in large quantity and mood states changed frequently. Besides, the story was mentioned among the 100 Classical Works, which showed it was eligible for the study. After selecting the text, the important parts in the story were identified and a pool of 10 items about those parts was created. Following a revision, five of the items were omitted and an achievement test of five items was developed. For the second part of the study, a case that the students were likely to experience in daily life was selected. In the case, the students were given some of the events they would experience on their birthday in order and in a story line. The students were asked to express their feelings and ideas they would have as a result of the events they would experience in the story by drawing emoticons. The consultancy of two experts from educational sciences and one expert from child psychology was asked. At the end of the evaluation, twelve of the twenty five items from the pool were omitted and the 8-item case study analysis items were completed. The achievement test of 5+8 items (reading comprehension, case study analysis items) was taken by students.

\subsection{Data collection procedures}

The achievement test developed for students to express their feelings and ideas consisted of different parts. In the first part, the students were asked to tell what they understood from the text by using the emoticons. In the second part, the students were asked to choose a case and draw emoticons that would express their feelings and ideas about this case. For the second part of the study, a case that the students were likely to experience in daily life was selected. In the case, the students were given some of the events they would experience on their birthday in order and in a story line. The students were asked to express their feelings and ideas they would have as a result of the events they would experience in the story by drawing emoticons.

\subsection{Data analysis}

A pilot application was conducted to control the data collection process. And a different study group was chosen for the pilot application. Demographic characteristics and grade levels of this group were similar to other groups. As result of the pilot application, problems of the application process were identified and resolved. Collected data were given to three different scorers for evaluation. For the interrater reliability, grading keys of the items were prepared. Data were analyzed by those grading keys. The results gathered from different scorers were evaluated. The limitations of the study are as follows: Due to the number of references in the literature on the subject was limited certain studies were carried out on the subject. Just students in a particular elementary school participated in this study.

\section{Results}

\subsection{Findings related to the first research question}

Findings related to the first research question [How is the role of emoticon on students to convey their critical and creative feelings and thoughts in reading, understanding and interpreting skills (reading skill)?] were included in this section. The data collected were examined in detail. As a result of this analysis, the scores of the students were given by the following graphs. The results obtained in this 
analysis were evaluated in the relevant section. Findings reached in the study were given below. The qualitative findings were resolved in the relevant sections.

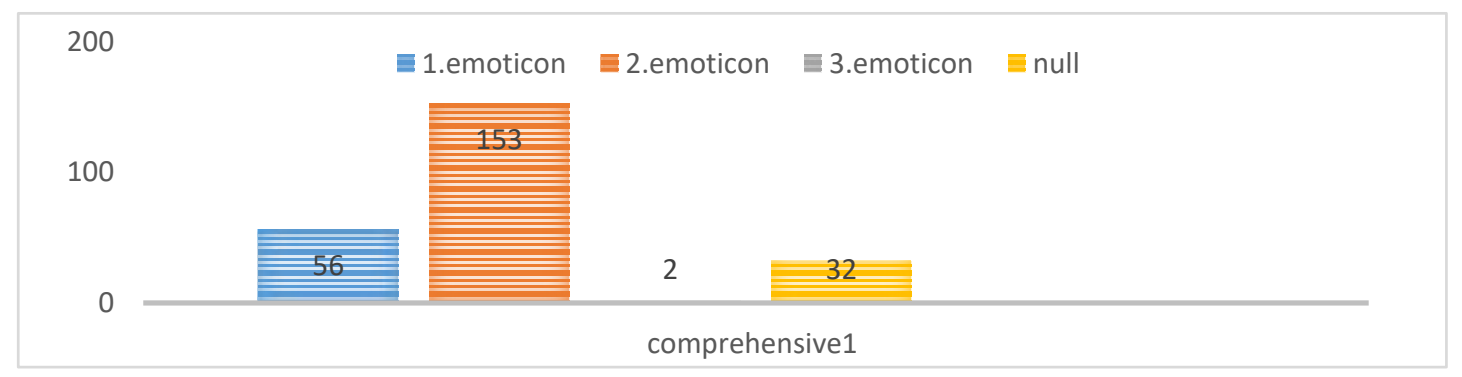

Graphic 1. Answers given by students to Item 1 in the reading comprehension achievement test

Graphic 1 explored students' skills to express their comprehension of the story by using emoticons. Students were asked to choose the correct emoticon among others to express the scary situation faced by the mouse, one of the characters in the study. The mouse says: "This pond is quite big and deep. I'm afraid of getting drowned." Most of the students chose the second face, which was the correct option for scare. Students chose the $3^{\text {rd }}$ emoticon the least because the happy face in this option was not anywhere near the correct option. This showed that the participants were highly good at identifying the emoticons drawn to express feelings.

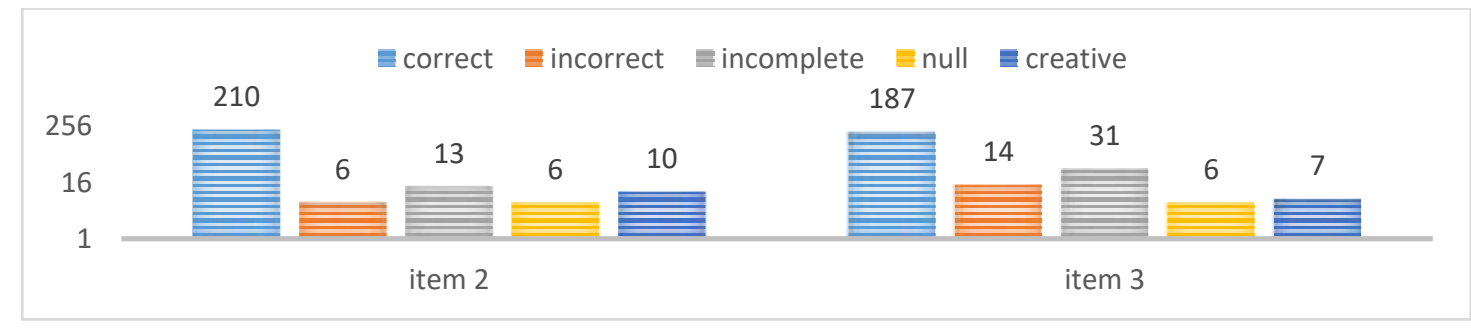

Graphic 2. Answers given for item 2 and item 3

In Graphic 2 students were asked to draw the face of the mouse before encountering water and after encountering water (Item2). This item aimed to identify how the participants would express the mood state they identified correctly in item 1 with an emoticon and to see how the changed mood states were reflected through emoticons. Graphic 2 showed that almost all participants drew the correct emoticon. The participants drew happy, confident, conceited, etc. faces to describe the mouse's mood before it encountered water; and they drew worried, scared, uneasy faces to describe the mouse's mood after it encountered water. In the first emoticon the happy, confident and conceited face of the mouse was drawn. In the second emoticon, on the other hand, it was observed that the mouse's self-confidence had vanished and this was creatively criticized by the participants through worried and scared faces. Thus, the participants were able to picture the case correctly through emoticons from a critical point of view. This finding suggested that the participants were able to picture the case they identified correctly in the previous item through emoticons from a critical point of view. However, a small number of participants drew the mouse's face incompletely or incorrectly whereas some of them left this item unanswered.

Item 3 examined how the opposite mood states in the story were perceived and how they were reflected through emoticons. To that end, the participants were asked to draw the expression of the face of the camel before it encountered water and after it encountered water. This item observed how the different moods of the two opposite characters in the same story were perceived by the participants and 
how these different moods of the characters were described by the participants from a critical point of view. The camel was a wise and proud character and maintained this attitude until the end of the story. Therefore, the self-confident camel was expected to be pictured through similar emoticons both at the beginning and end of the story. The drawings showed that the facial expressions of the camel before and after encountering water were drawn similar to one another, if not the same. The participants described the facial expression of the camel before and after encountering water through wise, self-confident and proud, calm, patient, etc. faces. Some of the participants supported their drawings by adding critical words or sentences to them. Some of the participants went beyond that and drew highly creative emoticons in order to criticize the difference between the mouse and the camel. A very small amount of the participants drew incomplete or incorrect emoticons while some of the participants left this item unanswered. However, in general participation rate for both items was high and close to one another.

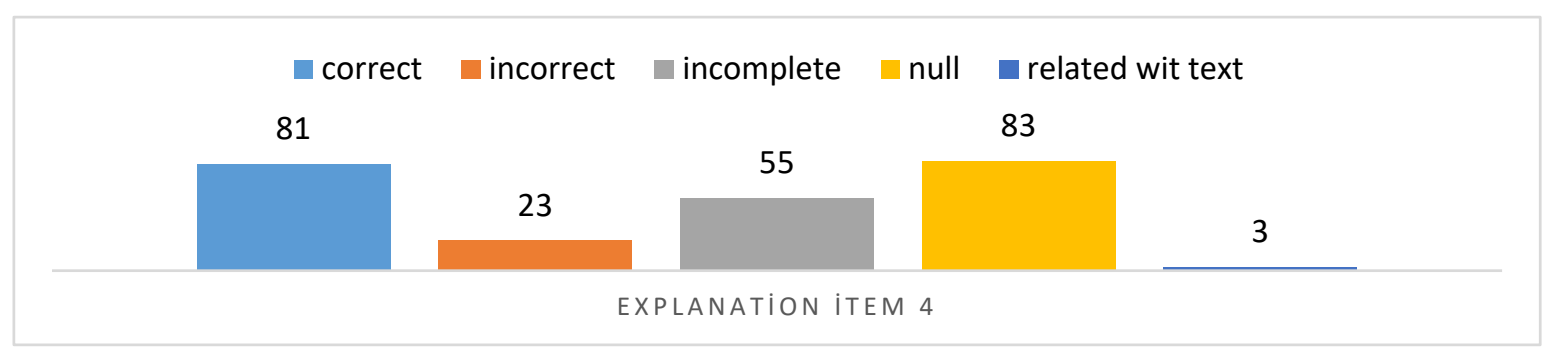

Graphic 3A. Answers given for item 4A.

In this part of the study, the relation between the description the participants made for a certain character in a story and the emoticon drawn by the participants based on the said description was examined. In other words, the participants' skills to describe the scheme in their minds and to transform these schemes into icons from a critical and creative point of view were probed. To this end, the participants were asked to describe the person or people addressed by Mevlânâ as such: Be someone from ordinary people because you are not the sultan. Do no attempt to steer the ship by yourself because you are not the captain. Graphic $3 \mathrm{~A}$ showed the answers to this item. It was aimed to identify how the participants would describe the characters they had in mind on paper. Graphic 3A showed that most of the participants left this item unanswered or answered incompletely or incorrectly. This suggested that the participants were not interested in describing the character in the story on paper or they had difficulty in doing so. The fact that the rate of providing answers by relating them to the text was relatively low supported this finding. Most of the participants who answered the item correctly described the addressee with words like arrogant, haughty, disdainful, supercilious, etc. However, it cannot be claimed that the participants were able to explain a scheme in their minds successfully since the number of the participants who answered the item correctly was far low than the number of the participants who left the item unanswered or incorrectly or incompletely. It showed that the participants who successfully expressed what they read in Item 1 and Item 2 through emoticons were not able to prove the same interest and success in expressing their understanding on paper in writing. Therefore it could be concluded say that the participants' skills to express what they read through emoticons from a critical and creative point of view were better than their skills to express it in writing. 


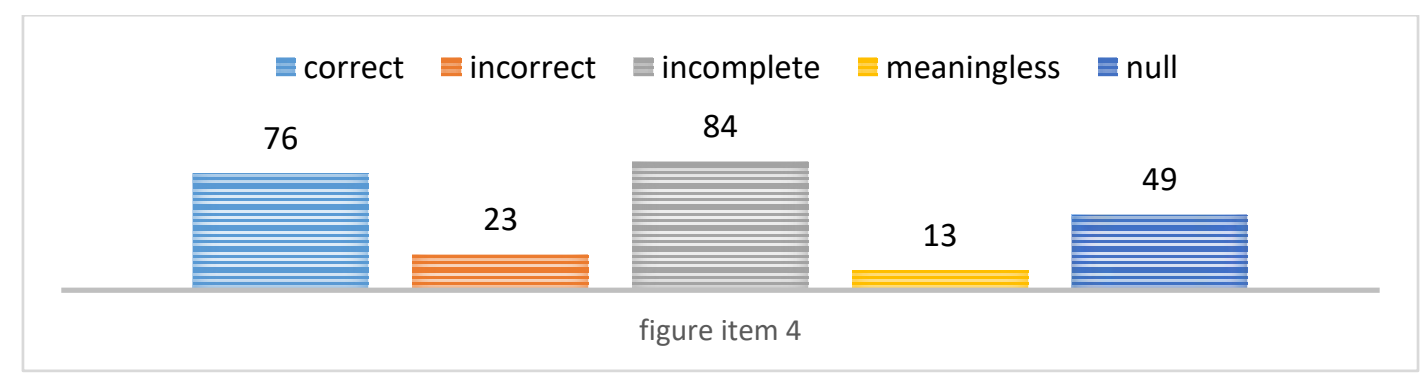

Graphic 3B. Answers given for item 4B

To further support this finding, in Graphic 3B, were examined the drawings of the participants who provided the correct answer. The participants successfully pictured those people they described as "arrogant, haughty, disdainful, supercilious, etc. through critical and creative emoticons.

\subsection{Findings related to the second research question}

Findings related to the second research question (How is the role of emoticons on the students' skills to convey their feelings and thoughts critically and creatively?) were included in this section. Findings related to this research question were given in the related sections below.

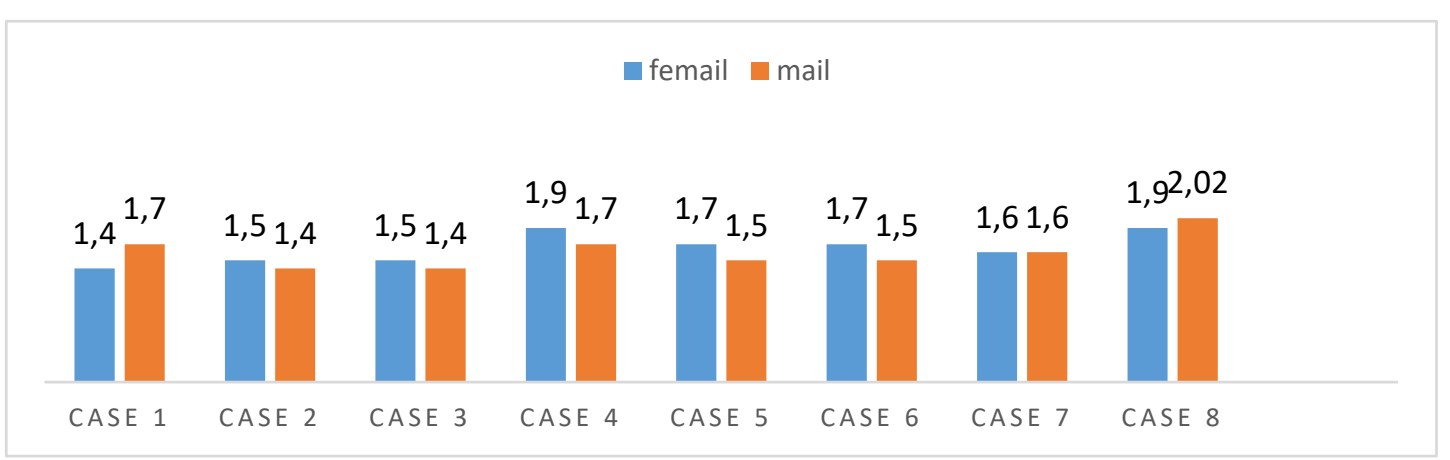

Graphic 4. The rate of the use of emoticons by male and female students in the case

This part of the study examined the rate of expressing feelings and ideas in a case in a critical and creative way by using emoticons by male and female students. The participants were asked to imagine that it was their birthday and a course of events were given within this context that they were likely to experience on such a day. Eight different cases were given and the participants were asked to express the feelings and ideas they were likely to have in such cases by using emoticons. Graphic 4 showed that cases (birthday) 4 and 8 had the highest participation rates. Cases (birthday) 2 and 3 were the ones where participation rate was the lowest while participation rate was quite close to one another in other cases. In case 8 , where participation rate was high, when the participation rate by male and female participants was taken into account, it was understood that this case was the one which had been addressed by male participants most compared to other cases. Although the second step of the case (birthday2) was addressed less compared to other phases, female participation rate was higher than male participation rate. A similar case in the third case (birthday3) was observed. In cases four, five and six, where general participation rate was high, female participation rate was higher than male participation rate. It was curious that male participation was the highest in the eighth case where general participation rate was also the highest. As for the seventh case, male and female participation was quite close to one another. 


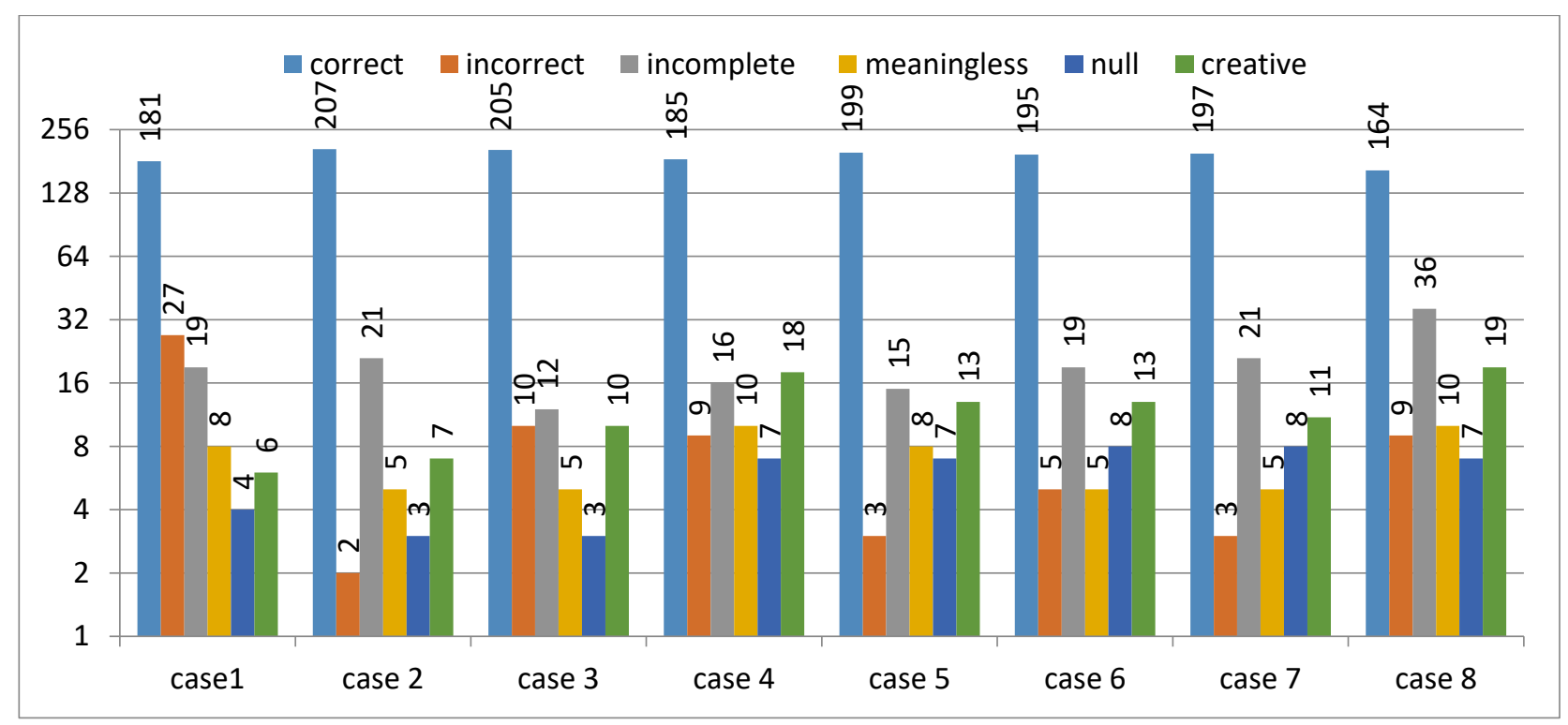

Graphic 5. The rate of using emoticons in 8 cases

This part of the study examined the participants' skills to express their feelings and ideas by using emoticons based on their experiences in the case. In the $1^{\text {st }}$ step, the participants were given the following case: "Imagine today is your birthday. You are so excited and can't wait to go home and see your birthday surprise by your parents. So you are looking forward to the end of the class. However, it is your second class yet and time passes too slowly for you. What kind of a face would you draw to express your impatience?" Most of the participants expressed their assumed facial expression correctly by creatively-drawn impatient, excited and bored emoticons. In this stage 181 participants handled the case quite creatively, drawing emoticons that were bored to death with puffed cheeks, looking impatient, worried, excited, sunk-eyed, pale-looking, lackadaisical, bored, etc. and added some expressions indicating time. 27 of the participants drew incorrect emoticons while 19 of them drew incomplete emoticons. 8 of the participants drew emoticons that were meaningless to the context and 4 participants left the question unanswered (case 1).

In the second stage, the participants were asked to draw emoticons to express their feelings and ideas they would have in the following (case 2) "The last bell rings at last and you hurry up for your way home. When you get home, you see a huge chocolate bar on the table (your favorite chocolate, by the way). How would your face look when you see the chocolate bar?" case 2 indicated that this case had been the one where the participants were able to express themselves best and felt comfortable (207). The participants drew surprised, happy, drooling, appetent, etc. emoticons and some supported their emoticons with verbal expressions, thus expressed themselves in a correct, creative and comfortable way. The participants were able to express themselves quite creatively, too, in the next stage where the following case was given: "And just when you reach for the chocolate, you are caught by your mother, who tells you: 'You ate a big chocolate yesterday, too much chocolate is not good for your health. So this chocolate is not yours. "' Most of the participants (205) protested the case by drawing disappointed faces (case 3). Some of them successfully expressed their level of upset through exaggerated critical drawings (tears overflowing the paper). In the $4^{\text {th }}$ stage, the participants were given the following case (case 4) "You slowly head for your room in disappointment. Hour follows hour, but nobody remembers that it is your birthday today. It is a terrible day for you because you gradually become convinced that your family has forgotten your birthday. It has been hours but there is nothing different. You are hopeless. "This case was drawn successfully, too. When the participants' skills to express their assumed feelings in the given context through emoticons were examined, it was seen that 185 participants were 
able to express themselves correctly; 16 participants drew the emoticons incompletely, while 9 participants drew incorrect emoticons that were irrelevant to the context, 10 of the participants drew emoticons that were meaningless to the context and 7 participants left the item unanswered.

In the $5^{\text {th }}$ stage (case 5), it was understood that the participants drew the emoticons more correctly compared to the previous case to express themselves. The following case was given: "There isn't a fun cartoon on TV to scatter the clouds of disappointment either. It is raining cats and dogs, you can't go to the playground. While you are thinking of all this, you hear a knock at the door, your mom says from the kitchen: 'Can you take care of it, honey? I'm in the middle of something.' You wonder about the visitor while you head for the door. When you open it, oh my Gosh, you can 't believe it! It is your dearest cousin who has been abroad for many years. This is so unexpected that you feel surprised rather than happy." 199 participants described the situation quite clearly and correctly with the creatively-drawn emoticons which consisted of absolutely surprised, hilariously happy, first surprised then happy faces. 15 of the participants drew incomplete emoticons while 8 participants provided meaningless emoticons. 13 of the participants provided highly creative emoticons while 3 participants drew incorrect emoticons and 7 participants left the item unanswered.

It was seen that the rate of using emoticons correctly decreased after this case as of stage 6 (case 6). It was possible to relate this to incomplete drawings because as of this stage, while the number of correct drawings decreased (the rate of which was low, though), the number of incomplete drawings increased (the rate was quite low). Below is a breakdown of how the participants expressed themselves through emoticons for the three cases given one by one. "You give a passionate and affectionate hug to your cousin and let her/him in. Just as you get rid of this heap of surprise, you see your mother coming to the living room with a birthday cake. Your favorite one, it already waters your mouth. Could you please draw an emoticon to describe this state of yours?" (case 6). This case explored participants' drawings describing their facial expressions that appeared when they saw someone they loved so much after a long and boring waiting process. 195 of the participants described the situation correctly and effectively by drawing happy, surprised and happy faces, some participants even drew faces with eyes wide open. 13 of the participants described the situation using rather creative emoticons. 19 of the participants drew incomplete, 5 of the participants drew meaningless and 5 of the participants drew incorrect emoticons while 8 of the participants left the item unanswered. In the $7^{\text {th }}$ stage the participants were asked to draw emoticons to express their feelings and ideas they would have in the following case (case 7): "Then there is another knock at the door and your dad, the rest of the family and all of your dear friends come home. You are together with all your dearest and nearest on your birthday." Graphic 5 showed that the participation rate in this case was rather high, which was curious. 197 of the participants expressed themselves creatively by drawing smiling, peaceful, happy emoticons. However, the number of incomplete drawings in this item was higher compared to the number of incomplete drawings in other items (21). 3 of the participants drew incorrect and 5 of the participants drew meaningless emoticons while 11 of the participants expressed their feelings and ideas through highly creative drawings.

In the last case of the case study, an unexpected twist was made in the end of the story, thus a rapid change was manipulated on the feelings. The course of events, which had been positive till this stage, took a negative direction. The case was stated at the last stage of the course of events: "After eating the delicious cake your mom has made for you, you are given your birthday gifts by everybody present there. All of the gifts are so beautiful and to the point to fill a niche. However, one of your friends mocks at a gift given to you by another friend." As is seen, the attitude of the former upsets the latter. How the participants expressed their feelings and ideas for this unexpected and critical state is as follows: 164 of the participants drew angry, frustrated faces with steam from ears to express their frustration for the mocking kid, while they pictured the mocked kid with sad, unhappy, ready to cry, embarrassed, etc. faces, thus criticizing the case creatively (case 8). It was observed that the number of correct emoticons 
was relatively smaller compared to the number of correct emoticons drawn for other items. The reason could be that children were able to draw emoticons expressing positive feelings more easily and successfully than they drew emoticons expressing negative feelings (Visser et al., 2008, 306; Ganster et al., 2012, 229).

\section{Discussion}

One of the most concrete findings of this study is that people can visualize many objects or situations in their minds they see or perceive in the world of tangible objects. Picturing this world of tangible objects on the canvas of our minds have continued for centuries and will continue to be so in the future because people transform their perception of objects into the qualitative structures of icons (iconic representation) and reveal these through images (Bruner, 1973).

In the present study, the participants transformed their understandings from a story and their reactions against cases they experienced in daily life into the qualitative structures of icons and imaged them in a creative way. While some of the participants created new and highly creative emoticons during this imaging process, some of them chose the one that would meet their needs from the existing emoticon pool and thus created their feelings and ideas. Participants with creative drawings expressed themselves so originally while transferring their feelings and ideas through emoticons. In other words, these participants didn't choose to use a universal emoticon that would describe the case even if they knew it and created their own emoticons to express themselves in a more original way. This showed that no matter how universal the emoticons were, they still promoted individual creativity. These original emoticons were the outputs of the participants' creative and critical thinking skills and these emoticons could be called creative emoticons. The most prominent property of such emoticons was that even if they had a universal identity, they could become original through creative drawings while transferring a common emotion. The number of emoticons chosen by the participants from the existing emoticon pool to meet their needs best had been quite high in the present study. The emoticons used in this group could be called selective emoticons. It was observed that even if the selective emoticons were universal, they could be made original through a critical point of view.

It was observed that some of the participants drew both the creative and selective emoticons incompletely, in other words, they left the creative emoticons they drew to express their feelings and ideas incompletely or they did not finish some of the selective emoticons completely. The emoticons in this category thus could be called incomplete emoticons. The main reason for this was that some of the participants were not fully express their feelings and ideas. Another reason could be related to participants' lack of full understanding of the source they listened to, watched or read. It was observed that due to these two reasons, the participants could produce incorrect drawings as well as incomplete ones as it was identified that the cases and situations both in the story and case study were quite different from the ones described by the participants through emoticons. To put it simpler, the plots in the stories did not match to the drawings.

Another remarkable finding of the study was that the participants had been remarkably successful in transferring what they had understood from the text through emoticons (Graphic 1 and 2). The mean for correct answers in Graphic 1 and Graphic 2 were much higher and some of the drawings were impressively creative.

As is seen in Graphic 3A and 3B, children preferred explaining the texts they had read by drawing emoticons to making that explanation through writing. The reason behind this preference might be that emoticons were considered to be a more creative, freer and more entertaining tool for communication for children. This result also was supported by the results of previous studies (Sönmez, 2018; Siegel et 
al., 2015; Huang et al., 2008; Oto et al., 2002). This property of emoticons might help students who are shy, introverted, and quiet and have difficulty in expressing their feelings and ideas, thus emoticons can be used as a means to encourage such students to participate in lessons during classes. Through this, teachers can both ensure the active participation of all students in the class and keep them motivated, interested and focused.

\section{Conclusions}

As seen in previous studies, emoticons were classified according to their usage characteristics in different ways (Skovholt and Kankaanranta, 2014; Locke and Daly, 2007; Weiquan, Zhao and Lingyun, 2014). In this study, emoticons were classified according to the results obtained. Taking this into account, it could be possible to classify the emoticons according to their shapes and the need for use under the titles of creative, selective and incomplete. The rate of usage of the emoticons showed that selective emoticons were the ones that had been preferred the most. This suggested that a great majority of the children preferred using universal emoticons to express their feelings and ideas. The fact that these universal emoticons were used by children so frequently led to think that they should be effectively utilized during learning and teaching processes because emoticons were used by students as an entertaining, critical and creative means for communication and they might have helping and supplementary roles in the actualization of academic aims.

It suggested that the emoticon had been perceived correctly in Graphic 1 and thus had been drawn correctly in Graphic 2. This allowed room to suggest that emoticons could be utilized to allow students of each grade, primary students being in the first place, to creatively express the schemes reflected in their minds upon reading a text. The present study showed that children's enthusiasm and ability to express the schemes in their minds through emoticons was more and much better than their enthusiasm and ability to express them through alphabet.

Any approach, method, technique or tool adopted for any type of communication has different outcomes on different genders. In the present study, it was identified that emoticons had almost the same rate of effect on both male and female participants because the need of participants from each gender to use the emoticons to express their feelings and ideas in a creative and critical way was very close to one another. Therefore, the results of this study differ from some of previous studies (Wolf, 2000; Hudson at al., 2015).

Emoticons the use of which does not differ by gender should be improved and used more frequently in the constructivist learning environment since it is compulsory to organize the approaches, methods, techniques, strategies and tools for an effective education according to the interests and needs of the students.

\section{References}

Bruner, J.S. (1973). Organization of early skilled action. Child Development, 44, 1-11.

Churches O, Nicholls M., Thiessen M., Kohler M. \& Keage H. (2014). Emoticons in mind: an eventrelated potential study. Social Neuroscience, 9 (2), 196-202.

Creswell, J.W. (2013). Nitel araştırma yöntemleri beş yaklaşıma göre nitel araştırma ve araştırma deseni (Mesut Bütün ve Selçuk Beşir Demir Çev. Edt.). Ankara, Siyasal Kitapevi. 
Ganster T., Eimler S. C. \& Kra"Mer, N. C. (2012). Same but different!? the differential influence of smilies and emoticons on person perception. Cyberpsychology, Behavior and Social Networking, 15 (4), 226-231.

Gürçayır, S. (2009). "İnternet çağının hiyeroglifleri” ya da evrenselleşen sanal bedenler: MSN ifadeleri. Millî Folklor, 83, 111-15.

Halvorsen. A. (2000). Patterns of emoticon usage in ESL students' discussion forum writing. Calico Journal, 29(4), 694-717.

Huang, A. H, Yen, D. C. \& Zhang, X. (2008). Exploring the potential effects of emoticons. Information \& Management, 45, 466-473.

Hudson, M., Sylis N., Howser M., Lipsett K., Robinson, W. Pope L. J, Hobby, A. F. \& Friedman, D. R. (2015). Examining how gender and emoticons influence facebook jealousy. Cyberpsychology, Behavior and Social Networking, 18(2), 87-92.

Locke, T. \& Daly, N. (2007). The place of politeness in asynchronous online discussion. International Journal of Learning, 13(12), 121-134.

Oto, S., Pelit, A. \& Aydın, P. (2002). Non-concordance in amblyopia treatment: the effective use of 'smileys'. Strabismus, 10(1) 23-30.

Siegel, R. M. Anneken, A., Duffy C., Simmons K., Hudgens M., Lockhart, M. \& Shelly, J. (2015). Emoticon use increases plain milk and vegetable purchase in a school cafeteria without adversely affecting total milk purchase. Clinical Therapeutics, 37(9), 1938-1943.

Skovholt, K. \& Kankaanranta, A. (2014). The communicative functions of emoticons in workplace emails: :). Journal of Computer-Mediated Communication, 19, 780-797.

Sönmez, H. (2018). Emoticonların iletişim aracı olarak kullanılmasına yönelik öğrenci tutumlarının incelenmesi. Kastamonu Education Journal, 26(4), 1081-1089. doi:10.24106/kefdergi.433434

Visser, N., Alant, E. \& Harty, M. (2008). Which graphic symbols do 4-year-old children choose to represent each of the four basic emotions? Augmentative and Alternative Communication, 24 (4), 302-312.

Weiquan, W., Zhao, Z. Y. \& Lingyun, Y. Q. (2014). Effects of emoticons on the acceptance of negative feedback in computer mediated communication. Journal of the Association for Information Systems, 15(8), 454-483.

Wolf, A. (2000). Emotional expression online: gender differences in emoticon use. Cyberpsychology \& Behavior, (3), 5. 


\section{Anlatma becerilerinde bir iletişim aracı olarak kullanılan emoticon tekniğinin incelenmesi}

\section{Öz}

$\mathrm{Bu}$ araştırmanın amacı, öğrencilerin duygu ve düşüncelerini emoticonları kullanarak eleştirel ve yaratıcı olarak nasıl anlattıklarını incelemektir. Birinci bölümde, öğrencilerin okuduklarından hareketle anladıklarını emoticon kullanarak nasıl anlattıkları incelenmiştir. Öğrencilerin okuduğunu anlama ve bunları emoticonlarla anlatma becerilerini ölçmek amacıyla geliştirilen başarı testi uygulanmıştır. İkinci bölümde örnek olay incelemesi yapılmıştır. Örnek olaydan hareketle vaka analiz süreçleri (maddeleri) tasarlanmıştır. Pilot uygulama sonucunda hem başarı testi ve hem de örnek olayın vaka analiz süreçleri (maddeleri) gözden geçirilip tamamlanmıştır. Asıl uygulamada elde edilen sonuçlara göre öğrencilerin hem okuduklarından anladıklarını hem de yaşadığı olaylarıyla ilgili duygu ve düşüncelerini (anlatma) emoticonları kullanarak eleştirel ve yaratıcı bir şekilde aktardığı belirlenmiş̧tir. Bu bulgudan hareketle dünyanın birçok yerinde kullanılan emoticonların eğitimde bilinçli bir şekilde yer alması gerektiği önerilmiştir.

Anahtar sözcükler: İletişim arac1; öğrenci; emoticonlar; teknik

\section{AUTHOR BIODATA}

Author started her high school education at Kilis Nedim Ökmen Anatolian Teacher's High School and for her license degree she graduated from Department of Turkish Language and Literature Teaching, Van Yüzüncü Yıl University. In 2008, she started working as a research assistant at the Department of Turkish Language Teaching, Faculty of Education, Muş Alparslan University. For master she graduated from Institute of Educational Sciences, Department of Turkish Language Teaching, Department of Turkish Language Teaching, İnönü University in 2011. For $\mathrm{PhD}$ she graduated from Institute of Educational Sciences, Department of Turkish Language Teaching, Marmara University, in 2017. In 2018 she started to work as Dr. Instructor at Faculty of Education, Department of Turkish Language Teaching, Muş Alparslan University and she still continues to work there. 